\title{
BURKITT-LIKE LYMPHOMA IN AN INFANT: A CASE REPORT
}

\author{
Claudete Esteves Klumb, Lídia Maria Magalhães de Resende, Claudio Gustavo \\ Stefanoff, Carlos Humberto Vicuña, Ilana Zalcberg Renault, and Raquel \\ Ciuvalschi Maia
} KLUMB CE et al. - Burkitt-like lymphoma in an infant: a case report. Rev. Hosp. Clín. Fac. Med. S. Paulo 58(1):33-36,
2003.

Childhood non-Hodgkin's lymphomas, including Burkitt and Burkitt-like, are rarely diagnosed in infants. A case of Bcell lymphoma in a 13-month-old girl with extensive abdominal disease, ascites, pleural effusion, and tumor lysis syndrome is reported. Phenotypic analysis showed a germinal center B-cell phenotype, and a B-cell clonality was confirmed by polymerase chain reaction. There was no evidence of Epstein-Barr and HIV infection. The case herein reported emphasizes the need for considering the diagnosis of lymphoma even in very young children.

DESCRIPTORS: Non-Hodgkin lymphoma. Burkitt lymphoma. Burkitt-like lymphoma. Infant. Childhood cancer.

\section{INTRODUCTION}

Non-Hodgkin's lymphoma (NHL) is a rare disease in the very young children $^{1,2}$. Small noncleaved cell lymphoma (SNCCL) and Burkitt's and Burkitt-like lymphomas comprise $40 \%$ - $50 \%$ of childhood lymphomas ${ }^{3}$. The incidence of SNCCL is age-dependent, being much higher in the first 2 decades of life; SNCCL has not been reported in children under 2 years of age. These lymphomas are B cell in origin and have the immunophenotypic characteristics of a subset of germinal center cells. Rare cases of Burkitt and Burkitt-like lymphoma have been reported in infants ${ }^{2,3}$. We herein describe a case of a Burkitt-like SNCCL in a very young child.

\section{CASE REPORT}

A 13-month-old female infant developed diarrhea and failure to thrive. Physical examination revealed a mass in lower abdominal quadrant and ascites. Computed tomography showed extensive intra-abdominal disease and right pleural effusion. Laboratory findings showed: red blood count, $3.67 \mathrm{x}$ $10^{12} / \mathrm{L}$; hemoglobin concentration, $9.5 \mathrm{~g} / \mathrm{dL}$; haematocrit, $29 \%$; platelet count, $514 \times 10^{6} / \mathrm{L}$; white blood cell count, $10.9 \times 10^{6} / \mathrm{L}$ with $31 \%$ lymphocytes and $76 \%$ neutrophils.

From the Cancer Hospital, National Institute of Cancer - Rio de Janeiro.

Received for publication on February 14, 2002.
High blood levels of lactic dehydrogenase (LDH), $2171 \mathrm{IU}$, and uric acid $(9.2 \mathrm{mg} / \mathrm{dL})$ were consistent with mild tumor lysis syndrome. An exploratory laparatomy was performed and revealed diffuse abdominal involvement including omentum and ovaries, which were biopsied. The histopathological analysis showed neoplastic cells similar in appearance to those of Burkitt's lymphoma, but there was increased pleomorphism over that accepted for Burkitt's lymphoma (greater variation in cell size and shape). The cells tended to have a more finely dispersed chromatin pattern and sometimes had a single prominent eosinophilic nucleolus. Burkitt-like SNCCL was diagnosed. Cytogenetic analysis was not performed in this case. 
Immunohistochemistry showed strong positivity for CD20 (L26 DAKO). Pleural effusion phenotypic analysis by flow cytometry was positive for HLA Dr, CD19, CD20, IgM, and CD45 and negative for $\mathrm{CD} 34, \mathrm{CD} 3, \mathrm{CD} 4$, and CD8. The cerebrospinal fluid and bone marrow were negative for the disease. The St. Jude staging system was applied, and the patient was classified as having stage III disease.

B-cell clonality was detected by PCR using oligonucleotide primers to amplify rearranged CDRII and CDRIII regions (semi-nested FR2-JH and FR3JH PCRs) of immunoglobulin heavy chain $(\operatorname{IgH})$ as described elsewhere ${ }^{4,5}$ (Fig. 1). The HIV test was negative in the child and her parents. In situ hybridization for Epstein-Barr encoded RNAs was negative. No evidence of immunodeficiency was found in this child. The patient was treated with a BFM (Berlin-Frankfurt-Münsten)based protocol ${ }^{6}$ and developed markedly elevated serum uric acid levels, severe electrolyte imbalance, and renal failure, but recovered with appropriate treatment. She remains alive, in complete remission for 30 months.

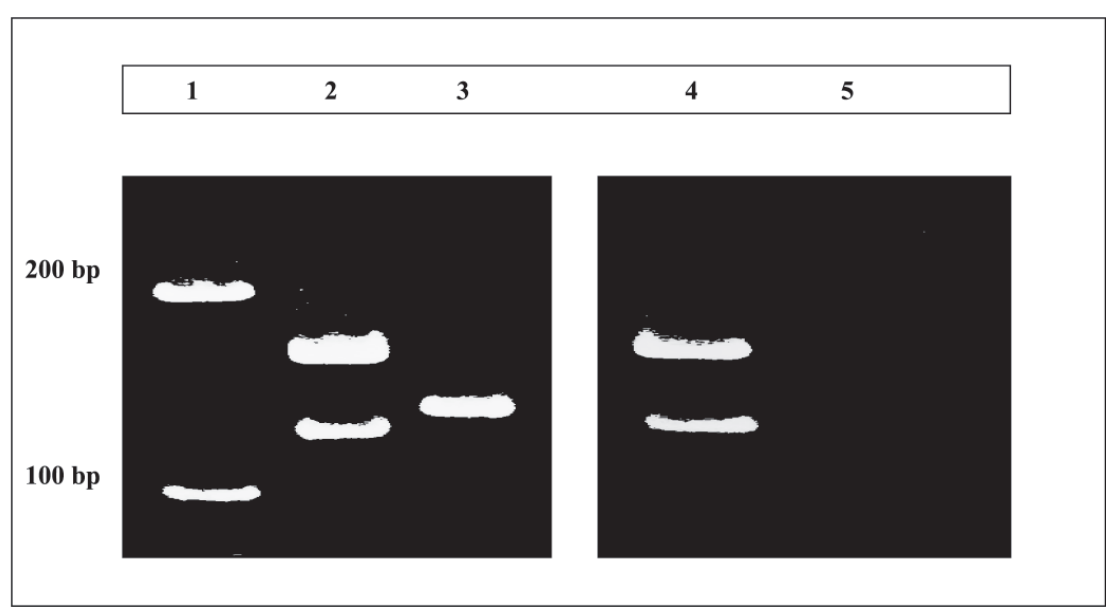

Figure 1 - Clonal IgH (CDRIII) gene rearrangement detected by FR3-JH polymerase chain reaction (PCR). Lane 1: 100 bp ladder (GIBCO-BRL) size marker; lane 2: biallelic rearrangement in pleural liquid, lane 3: positive control (Cemo-1 cell line); lane 4: rearrangement in abdominal tumor, identical pattern as pleural liquid; lane 5: PCR amplification without DNA template. Negative image of an $8 \%$ polyacrylamide gel with silver staining. cases classified as Burkitt-like lacked c-myc rearrangement and had different molecular pathogenesis than $\mathrm{BL}^{11,12}$. Unfortunately, in this case, the molecular distinction between the two categories was not performed, and the diagnosis was made according to the morphologic criteria defined by the REAL classification ${ }^{13}$.

This patient presented a B-cell lymphoma at an unusually young age at diagnosis. The histological examination revealed a Burkitt-like SNCCL. Non-Hodgkin's lymphoma (NHL) including Burkitt and Burkitt-like, are rarely described in infants. In 338 consecutive newly diagnosed children with NHL, Murphy et al., found that $4.8 \%$ of them were younger than 3 years of age ${ }^{1}$. Evans et al., reported 6 children who developed NHL before the age of 3 years associated with mother-to-child HIV transmission ${ }^{14}$. In another report of NHL in children with vertical HIV infection, $21.7 \%$ were under 2 years old ${ }^{15}$. We have identified 1 infant patient with a Burkitt-like SNCCL whose HIV test was negative in the child and her mother, and the EBV genome was not detected by in situ hybridization, despite the previously described relationship between young age and HIV infection and these lymphomas ${ }^{10,11}$.

Prior to the last two decades, childhood Burkitt's NHL was a fatal disease in most of the cases. In 1976, Wollner et al. reported the excellent results on the treatment of childhood NHL using a novel multiagent chemotherapeutic regimen, $\mathrm{LSA}_{2} \mathrm{~L}_{2}{ }^{16}$. Several reports in the past 10 years have shown that event-free survival has significantly improved $^{6,17-19}$. Patients with limited disease currently have an excellent prognosis $(90 \%-100 \%)^{6,17}$. The probability of cure is obviously influenced by many factors, among which the most important are the total body burden of tumor and intensity of chemotherapy ${ }^{6}$. The former is reflected 
mainly by the stage of disease and LDH serum level at diagnosis ${ }^{20}$. In the past, the prognosis for patients with high tumor burdens or with central nervous system involvement was very poor $^{21}$. This situation has changed markedly in recent years, and patients with stage III Burkitt and Burkitt-like
SNCCL including those with extensive intra-abdominal disease, have a $60 \%-80 \%$ long-term survival rate ${ }^{6,18}$. Tumor lysis syndrome is often present at diagnosis or after initiation of treatment. This emergent clinical situation should be anticipated prior to starting treatment. Despite the high tumor bur- den found, our patient achieved longterm complete remission, probably related to the intensive therapy.

The current report illustrates the importance of considering NHL in the differential diagnosis of neoplasia in very young children, even when HIV is not present.

\section{RESUMO}

KLUMB CE e col. - Linfoma burkittlike em um lactente: relato de caso. Rev. Hosp. Clín. Fac. Med. S. Paulo 58(1):33-36, 2003.

Os linfomas não Hodgkin da infância, incluindo os linfomas de Burkitt e Burkitt-like são raros em lactentes. Um caso de linfoma não Hodgkin B em uma lactente de 13 meses de idade é descrito. Ao diagnóstico a paciente apresentava extenso comprometimento abdominal associado à ascite, derrame pleural e síndrome de lise tumoral. A análise imunofenotípica mostrou um fenótipo compatível com células linfóides oriundas do centro germinativo e a origem clonal dessas células foi demonstrada por reação em cadeia da polimerase. Não foi demonstrada associação do linfoma com infec- ção pelo vírus Epstein-Barr e/ou virus da imunodeficiência adquirida. $\mathrm{O}$ caso apresentado enfatiza a necessidade de considerar o diagnóstico de linfoma mesmo em lactentes.

DESCRITORES: Linfoma nãoHodgkin. Linfoma de Burkitt. Linfoma Burkitt-like. Lactente. Neoplasias na infância.

\section{REFERENCES}

1. MURPHY SB, FAIRCLOUGH DL, HUTCHISON RE et al. - NonHodgkin's lymphomas of childhood: An analysis of the histology, staging, and response to the treatment of 338 cases at a single institution. J Clin Oncol 1989;7:186-193.

2. HUTCHISON RE, PUI CH, MURPHY SB et al. - Non-Hodgkin's lymphoma in children younger than 3 years. Cancer 1988;62:1371-1373.

3. MAGRATH IT - Small noncleaved cell lymphomas (Burkitt's and Burkitt-like lymphomas). In: MAGRATH IT - The nonHodgkin's lymphomas. $2^{\text {th }}$ ed. London, Arnold, 1997. p. 781805 .

4. YAMADA M, HUDSON S, TOURNAY O et al. - Detection of minimal disease in hematopoietic malignancies of the B-cell lineage by using third-complementarily-determining region (CDR-III)-specific probes. Proc Natl Acad Sci USA 1989;86: 5123-5127.
5. RAMASAMY I, BRISCO M \& MORLEY A. - Improved PCR method for detecting monoclonal immunoglobulin heavy chain rearrangement in B cell neoplasms. J Clin Pathol 1992;45:770-775

6. REITER A, SCHARAPPE M, TIEMANN M et al. - Improved treatment results in childhood B-cell neoplasms with tailored intensification of therapy: A report of Berlin-FrankfurtMünster Group trial NLH-BFM 90. Blood 1999;94:3294-3306.

7. NATIONAL Cancer Institute - The Non-Hodgkin's Lymphoma Pathologic Classification Project: National Cancer Institute sponsored study of classifications of non-Hodgkin's lymphomas: summary and description of working formulation for clinical usage. Cancer 1982;49:2112-2135.

8. SHIRAMIZU B, BARRIGA F, NEEQUAYE J et al. - Patterns of chromosomal breakpoint locations in Burkitt's lymphoma: Relevance to geography and Epstein-Barr virus association. Blood 1991;77:1516-1526. 
9. ARAUJO I, FOSS HD, BITTENCOURT A et al. - Expression of Epstein-Barr virus gene products in Burkitt's lymphoma in northeast Brazil. Blood 1996;87:5279-5286.

10. MAGRATH IT, BHATIA K. - Pathogenesis of small noncleaved cell lymphomas (Burkitt's lymphoma). In: MAGRATH IT The non-Hodgkin's lymphomas. $2^{\text {th }}$ ed. London, Arnold, 1997. p. 385-409.

11. YANO T, van KRIEKEN JHJM, MAGRATH IT et al. - Histogenetic correlations between subcategories of small noncleaved cell lymphomas. Blood 1992;79:1282-1290.

12. HUTCHISON RE, FINCH C, KEPNER et al. - Burkitt lymphoma is immunophenotypically different from Burkitt-like lymphoma in young persons. Ann Oncol 2000;Suppl 1:S35S38.

13. HARRIS NL, JAFFE ES, STEIN H et al. - A revised EuropeanAmerican classification of lymphoid neoplasms: A proposal from the International Lymphoma Study Group. Blood 1994;84:1361-92.

14. EVANS JÁ, GIBB DM, HOLLAND FJ et al. - Malignancies in UK children with HIV infection acquired from mother to child transmission. Arch Dis Child 1997; 76:330-333.

15. CASElli D, KLERSY C, MARTinO $M$ et al. - Human immunodeficiency virus-related cancer in children: incidence and treatment outcome report of the Italian Register. J Clin Oncol 2000; 18:3854-3861.
16. WOLLNER N, BURCHENAL JH, LIEBERMAN PH et al. - NonHodgkin's lymphoma in children: A comparative study of two modalities of therapy. Cancer 1976;37:123-134.

17. LINK MP, SHUSTER JJ, DONALDSON SS et al. - Treatment of children and young adults with early-stage non-Hodgkin's lymphoma. N Engl J Med 1997;337:1259-1266.

18. BRECHER ML, SCHWENN MR, COPPES MJ et al. - Fractionated cyclophosphamide and back-to-back high dose methotrexate and cytosine arabinoside improves outcome in patients with stage III high grade small non-cleaved cell lymphomas (SNCCL): A randomized trial of Pediatric Oncology Group. Med Pediatr Oncol 1997;29: 526-533.

19. ATRA A, GERRARD M, HOBSON R et al. - Improved cure rate in children with B-cell acute lymphoblastic leukaemia (BALL) and stage IV B-cell non-Hodgkin's lymphoma (B- NHL) - Results of the UKCCSG 9003 protocol. Br J Cancer 1998; 77:2281-2285.

20. MAGRATH I, LEE YH, ANDERSON T et al. - Prognostic factors in Burkitt's lymphoma: Importance of total tumor burden. Cancer 1980;45:1507-1515.

21. MURPHY SB. - Classification, staging, and end results of treatment of childhood non-Hodgkin's lymphomas: Dissimilarities from lymphomas in adults. Semin Oncol 1980;7:332-339. 